\title{
SENIOR ACADEMICS AS KEY NEGOTIATORS IN THE IMPLEMENTATION OF IMPACT POLICIES IN THE SOCIAL SCIENCES AND HUMANITIES
}

\author{
MARC VANHOLSBEECK, THEODOSIA DEMETRIOU, AGNE GIRKONTAITE, ANDREJA ISTENIC STARCIC, VILLE KEISKI, \\ EMANUEL KULCZYCKI, ELENA PAPANASTASIOU, JANNE PÖLÖNEN, HULDA PROPPE AND MAJA VEHOVEC \\ DOI: $10.22163 /$ fteval.2019.371
}

\begin{abstract}
Acknowledgement: This article is based on work from COST Action 15137 European Network for Research Evaluation in the SSH (ENRESSH) and supported by COST (European Cooperation in Science and Techno-
\end{abstract} logy).

$\mathrm{I}$ n this paper, we pursue two main objectives. First, we review the relevant literature and present it according to a theoretical framework that combines structural perspectives and consideration for individual agency, to allow us a better understanding of the role played by senior academics in the social sciences and humanities (SSH) in the implementation of the different policies that concern the production, the dissemination and the evaluation of research, including impact related policies. Indeed the academics' negotiating power of the impact agenda - as it is currently promoted by European policy makers (see e.g. European Commission 2018) and encompasses the impact on policy making, economy as well as the environment and society - cannot be understood in isolation of their perception and attitudes towards the broader political changes that affect the practice of academic research. Secondly we discuss some preliminary results from the interviews we have conducted in the context of the COST ENRESSH action with 16 European senior sociologists active in eight European countries, focusing here on their perceptions and attitudes towards the impact agenda.

\section{A. CHANGES IN THE RESEARCH POLICY MAKING}

Most current research policies and policy agendas in research can be considered, directly or indirectly, in the perspective of a few tendencies that have been initiated or fostered by research policy makers, both at national and European levels, and that concern STEM (Science, Technology, Engineering and Mathematics) as well as - often with some delay - SSH disciplines. We will distinguish between the tendencies towards internationalisation, digitalisation, managerialism, marketisation and "exoterisation" of research (Vanholsbeeck 2016).

Internationalisation relates to the tendency to encourage the production of research contents that focus on global phenomena, or comparisons of national situations, that are published in international journals - mostly in the English language - communicated at international conferences and imply geographical and/or virtual mobility of the researcher. In some disciplines, internationalisation has antedated policy prescriptions, following epistemological motives.

Digitalisation refers to the use of digital tools and media to produce and disseminate research.

Managerialism mostly consists in the adoption of "New Public Management" (NPM) in the administration of research. NPM relates to the introduction into the public sector of a diversity of managing practices and tools from the private sector, with an emphasis on the notions of efficiency, effectiveness, excellence, accountability and standards of performance (Hood 1995; Deem 1998; Enders et al. 2009; Whitley and Gläser 2014). In regards to human resources management, there is a related tendency - which constitutes one of the most important changes in the governance of research - to favour funding modes that combine recurrent with temporary project based funding, in a context of increasing scarcity of research budgets (Gläser and Laudel 2016: 121-122).

Marketisation relates to the tendency to consider universities, researchers and the research outputs themselves in the quasi-market perspective of a competitive knowledge economy, and to reconsider in this perspective the relations between academia and industries.

By the less usual notion of exoterisation we designate the various processes of opening the production, dissemination and evaluation of research outside (exo) of the disciplinary circles of the academic peers. In that respect, European and national level policies have supported the transfer of knowledge from researchers to non-academic stakeholders - in particular to the industry - as well as, more recently, the cocreation by researchers, policy makers, industries and/or citizens alike of solutions to societal challenges, under the influence of programmatic 
ideas such as "mode 2 of knowledge production" (Gibbons et al. 1994) or - in the context of the preparation of the next "European Research and Innovation Framework Programme "Horizon Europe" (2021-2027) - "missions" (Kattel and Mazzucato 2018). The European Open Science agenda ${ }^{1}$ - including open access to publications, open research data and citizen science - and the impact related policies also align with this tendency to exoterisation. The concept of exoterisation is thus broader than marketisation, since it includes social innovation - which can take non-commercial forms - and relates to the notion of knowledge society rather than to the sole knowledge economy.

If there is some degree of convergence between most of the above mentioned trends, the tendencies towards exoterisation and managerialism of research are not (yet) congruent, since performance indicators that are currently in usage in the management of research do not take into account in any significant way the extra-academic impact of research, nor open science practices (0'Carroll et al. 2017; Vanholsbeeck 2017).

\section{B. INSTITUTIONAL AND INDIVIDUAL PERSPECTIVES ON THE ROLE OF SENIOR ACADEMICS}

The role of senior academics in the implementation of research policies and science related political agendas, including the impact agenda, is better appreciated according to two theoretically different but eventually complementary perspectives: the institutionalist and the comprehensive - in the Weberian meaning of the term - approach. The first focuses on the structural determinants that impact individual behaviours, studying institutional pressures on collective organisations (at a meso-sociological level). The second takes the opposite perspective, focusing on the inner motivations and perceptions of individuals as well as to their agency, and dedicates attention on the impact that individual strategies and subjective interactions may have on organisations (at a micro-sociological level).

\section{INSTITUTIONALIST APPROACH}

Institution is a broad social science concept which, in the context of science sociology, can take two main meanings. It refers indeed to the official organisations in which science is practised (i.e.: universities, research centres, research units, academies, etc.), but also to the specific rules, processes and stable usages that weigh on the beliefs and behaviours of those who practice science (Gingras 2017: 29).

\subsection{INSTITUTION AS SCIENTIFIC ORGANISATION}

Of particular interest while considering changes in scientific organisations, the so-called "neo-institutionalist" school of sociology has renewed organisation theory, by focusing on the supra-individual cognitive and cultural factors that explain the social and organisational phenomena (DiMaggio and Powell 1991). Neo-institutionalists developed the concept of isomorphism, which explains why rational actors increase the similarity of organisations that have emerged as a certain field or domain, while trying to change them (DiMaggio and Powell 1983). Conceptual distinction has been made between coercive isomorphism - involving pressures from other organisations on which the organisation depends as well as social expectations surrounding them - mimetic isomorphism - consisting into an organisation imitating another organisation's structure because of the belief that such imitative process will be beneficial - and normative isomorphic process, relating to professional norms that span organisations belonging to the same field.

These three types of isomorphism are to some degree at work in contemporary academia, fostering similar moves towards internationalisation, marketisation and managerialism.

First, forms of coercive isomorphism can be found in the driving effect that performance quantitative indicators have on the practices they try to measure, in SSH research evaluation like in other areas of social life (as expressed for example in Campbell's or Goodhart's laws, according to which a measure ceases to be a good measure once it becomes a target). In particular, bibliometric indicators are increasingly used, both at European (Vanholsbeeck 2017) and national level (e.g. Hammarfelt et al. 2016; Pölönen and Wahlfors 2016), to benchmark national science systems and universities, but also to assess - and provide funding to - individuals and projects (De Rijcke et al. 2016; Gläser and Laudel 2016). Usually developed by private companies - such as the infamous Impact Factor (now provided by Clarivate Analytics) - bibliometrics is mostly based on international databases of scholarly journals. As such, they directly or indirectly coerce researchers in their publishing habits. They contribute to the rising proportion of the share of SSH publications that take the form of articles published, in English, in international journals (Hammarfelt and de Rijcke 2015; Kulczycki et al. 2018), even if any strictly causal ascription of the effects of a given research policy on research contents has to be considered with caution, because of the many confounding variables which are to consider (Gläser and Laudel 2016)2. Furthermore, some evaluation systems still take books and publications aimed at professional and general audiences into account (GiménezToledo et al. 2016).

Second, world university rankings which are in a significant part based on bibliometric indicators have become increasingly important in the last decade, not least due to their media exposure. Often produced by non-academic organisations, they exert some influence on universities around the world, promoting a global model of "world-class universities" worth following (mimetic isomorphism).

2 For example, it has been shown that the decrease in share of publications published in Finland, which is also partially indicative of publication language, is attested in the national publication statistics since 1994, well before the performance based funding model was established in Finland (Auranen and Pölönen 2014) 
Finally, efforts to standardise higher education - including third cycle and researchers' training - notably via the Bologna Process, contribute to some normative isomorphism within academia.

\section{ORGANISATIONS' REACTION TO INSTITUTIONAL PRESSURES}

In a meta-analysis of neo-institutional approaches and resource dependence theories, Oliver (1991) brought important nuances to the concept of isomorphism, and to the idea that organisations conform to the pressures of their institutional environment, benefitting from adhering to external rules and norms. She proposed a more nuanced typology of strategic responses to institutional process and active organisational behaviours that vary from passive conformity to active resistance, taking the form of acquiescence, compromise, avoidance, defiance or manipulation.

Relying on Oliver's typology and applying it to research organisations, Leisyte (2007) studied the effects of governance models on the research practices of research units in the fields of medieval history and biotechnology. She makes the distinction between three organisational strategies towards managerialism: passive compliance, symbolic compliance - a combination of acquiescence and avoidance consisting in pretension of compliance, but changing nothing to the way research is performed - and proactive manipulation of the rules and norms of the institutional environment.

It has to be noticed that local specificities have to be taken into account while considering the effect of managerialism on organisations and individuals alike (Stöckelová 2012). In particular, in former European socialist countries, the introduction of managerialism has accompanied a process of de- and re-politicisation (Linková and Stöckelová 2012).

\subsection{INSTITUTION AS A SET OF SOCIO-PROFESSIONAL VALUES}

According to the second of the abovementioned institutional definitions, the institution of science designates the specific social system of science. As such scientists are not only exposed to rules, processes and stable usages coming from the non-academic world, but also produce their very own socio-professional values, that span the boundaries of the organisations by whom they are employed.

In this perspective, the professional values of science have been analysed as a potential source of resistance to organisational changes in universities (Chandler et al. 2002; Kirkpatrick and Ackroyd 2003). Indeed, the values to which scientists adhere - such as academic freedom or the ones identified by Merton (1973), of communalism, universalism, disinterestedness and organised scepticism - may diverge from those that are supported by research policies in general, and by new public management in particular.

The discrepancies between the values of the scientific institution and the management of the scientific organisation may even create a clash between (internal) professional accountability, based on professional values, and (external) managerial accountability, based on managerial norms and processes (Linková and Stöckelová 2012). Hence some scientists engage in double allegiance: they "rarely seem to see themse/ves first and foremost as organisational members. Their allegiance is primarily to the disciplines or the institution of science, rather than its organisations. [...] They may even treat the universities, departments and institutes they are part of as irritations, a collection of performance indicators and management demands which threaten to get in the way of real science" (Davies and Horst 2016: 65).

In the same professional perspective, the relationships between senior researchers and PhD candidates - although little research has been carried out that focuses on $\mathrm{PhD}$ directors' reactions to the changing context of $\mathrm{PhD}$ education - constitute another place where professional values may conflict with organisational processes (Deuchar 2008; Bøgelund 2015).

It should be noted though that the dominant bibliometric performance indicators that are currently used in the new public management of research are still linked to the primary professional activity of academia. They mostly relate indeed to the production and citation of articles in scientific papers, and not to the engagement of the researchers in their organisation. Hence it can be argued that those indicators, although often criticised, are not entirely foreign to some core academic professional values.

\section{COMPREHENSIVE APPROACH}

Institutionalist perspectives should be combined with the analysis of the perceptions and attitudes of the individual researchers, with due consideration to their agency. Indeed scientific organisations provide individual scholars with a certain power to "negotiate" higher education and research policies (Linkova 2014), not the least because European universities do generally enjoy a high level of institutional autonomy, while the professional norm of academic freedom prevails in European higher education. Furthermore, some academics are active as full or parttime administrators in their institution, without being per se in an administrative career path. Senior academics are also those mostly in charge of leading a research team and training early stage researchers, assuring their professional socialisation.

The "comprehensive" literature that we reviewed in the context of this COST ENRESSH project resorts to a diversity of theoretical frameworks and concepts, some of them even referring to neo-institutionalism (e.g. Lam 2010 or Teelken 2011). Theoretical framing notwithstanding, most results tend to emphasise the ambivalent attitudes of researchers towards the abovementioned tendencies of marketisation, managerialism and exoterisation of research, bringing out at the individual level a similar attitude of "symbolic compliance" to the one that had been observed at the institutional level.

\section{REACTIONS TO MANAGERIALISM}

Most studies we reviewed concentrate on the scholars' reaction to managerialism, with an early focus on the UK situation. Already in 2001, it was contended that managerialism was not entirely embedded in UK universities, and that middle and junior level academics actively keep professional academic values alive and moderate the harsher effects of the changes (Barry et al. 2001). Deem (2003) has argued that the attitude towards managerialism of UK academic administrators varies depending on their intention to return later to teaching and research role. Those who intend to go back to primary academic tasks mitigate the new managerial language and keep some core professional values. Studying the 
negotiation of evolving research policies by UK life scientists, Morris and Rip (2006) similarly underlined that scientists develop more or less proactive strategies to modulate the impact of changing research policies.

Regarding SSH disciplines, Kehm and Leiðytë, on the basis of interviews with researchers in English medieval history units, also showed that they "try to find a balance between their own research agenda and the research priorities of the funding bodies [...]. They do so by following largely symbolic compliance strategies - maintaining their own research lines and at the same time selling their research interests according to the priorities of the external research funders" (Kehm and Leiðytë 2010: 80). Teelken (2011) analysed the individual behaviours of 48 academic and support staff members at ten universities in the Netherlands, Sweden and the UK, in faculties of social sciences and economics/business studies. The research shows that academics dissociate themselves from the managerial prescriptions, and appear to be only loosely coupled from their organisations, even if beside symbolic compliance and professional pragmatism (dealing with the managerial prescriptions "in a critical but serious manner"), an attitude of "formal instrumentality" is also observed (Teelken 2011: 278). Respondents do not consider assessment as such as undesirable, but are critical of the increasingly quantitative and time-consuming performance based assessment, as well as the growing competition for research funding. From interviews conducted with communication scholars in French speaking Belgium, Vanholsbeeck (2012) similarly concluded that those researchers, rather than fully accepting or resisting to the prescriptions that support the publication of (many) papers in international journals, are rather ambivalent towards the prescribed quality requirements. Some of them "tinker" with these prescriptions, trying to publish according to the (perceived) prescriptions, while still allowing time for publishing according to their very own definition of quality.

Focusing on the use of bibliometrics for evaluation purposes in Dutch law faculties, micro-politics of indicator use have also been revealed, through which scholars in advanced administrative positions try to proactively pursue "competing normative and epistemic agendas" rather than passively reacting to externally-imposed administrative procedures (Kaltenbrunner and de Rijcke 2016: 284). Comparably, Finnish and Norwegian universities use the national publication channel-based quality indicator for assessing individual academics, more particularly in the humanities. As such, the indicator is used as a replacement for publication counts, in lack of alternative indicators such as the Impact Factor in the SSH fields (Pölönen and Wahlfors 2016). Also in Finland, research on SSH researchers ( $\mathrm{N}=92$ ) has shown that the introduction of the new performance based funding model has involved what the authors call the "publication laundering" (in Finnish "julkaisupesu"), meaning the manipulation of publication lists to meet the standards, e.g. peer-review, of measured performances (Sivula et al. 2015: 153).

Some authors even contend that there are attitudes of real resistance, and not only of symbolic compliance, from academics to managerialism. Clegg maintains that academics do resist managerialism, albeit passively and individually, by creating spaces for the exercise of "principled personal autonomy and agency" which allow them to develop "their own ways of practising and a personal sphere of meaning" in which they can practise with integrity (Clegg 2008: 343). Similarly, Anderson finds that the resistance of Australian academics takes many forms and follows every day and covert discursive strategies, considering "academics' capacity - indeed, their perceived responsibility - to assess, analyse and criticize" as well as deeming them as particularly "skilled in rebellion and innovation" (Anderson 2008: 256 and 267). On the basis of interviews with Austrian historians, Kehm and Leiðytë (2010) identified a generation gap, senior researchers being more prone to resistance than early career academics who may have been professionally socialised in the new managerial context. Linková, studying the responses of Czech researchers in the humanities, social sciences, and natural sciences to research assessment, found that some academics engage daily in micro-politics of resistance and critiques which "are located within traditional 'Science' values stressing autonomy and peer judgment on the one hand or individual performance, primacy and competitiveness on the other" (Linkova 2014: 85-86). By doing so, they rely on traditional scientific values and stress autonomy and peer judgment, even if, overall, researchers show adaptation to the new types of governmentality.

The last category of articles we reviewed considers on the contrary that academics mostly - and not only symbolically - comply with the new managerial processes, and that resistance, whenever it happens, is essentially ideological or discursive, only a minority resisting actively. Those are the conclusions that Clarke, Knights and Jarvis (2012) have reached on the basis of their 48 interviews with British business school academics. Leathwood and Read (2013), as well as Ylijoki and Ursin (2013), made similar conclusions, respectively in regards to the British and Finnish academics they interviewed. A recent study of the introduction of performance appraisals in a regional Australian university showed little resistance either from academics' side, early career academics being particularly compliant with the new prescriptions. (Kalfa et al. 2018).

\section{MARKETISATION}

In regards to the tendency to the marketisation of research, it has been argued, on the basis of focused interviews with senior researchers in three different types of research settings in Finland (departments of History and Surface Science and Semiconductor Technology; Work Research Centre), that their engagement in "academic capitalism" depends on how close their field is from the market (Ylijoki 2003). The study shows that researchers try to accommodate traditional academic practices and values to more entrepreneurial activities, under the pressure of working increasingly on short-term contracts and projects. Similarly, a study based on 36 interviews and a survey of 734 academic scientists from five UK research universities shows the active agency of academics in the shaping of the relationships between science and business (Lam 2010). Most academics exploit the ambiguities of "boundary work" between academia and industry, rather than being entirely "traditional" or "entrepreneurial".

\section{ATTITUDES TOWARDS EXTRA-ACADEMIC IMPACT}

As far as we know, there is no dedicated research on the researchers' perception of impact policies as such, wherever such policies do exist in an explicit form. In their abovementioned study of the effects of the managerialism on research, Kehm and Leiðytë (2010) showed that the prescriptions to publish for a broader public, combined to the prescriptions in favour of more interdisciplinary research, have affected the research topics on which German medieval historians are working. Furthermore, the findings of Smith (2010) suggest that the growing pressure to 
produce policy relevant research in health inequality is diminishing the autonomy and creativity of sociologists, and is instead promoting the construction of institutionalised and vehicular ideas.

Other studies focus on the perception of scholars on science communication, public engagement and valorisation of research. In their review of past studies and surveys on how scientists view the public, the goals of communication, the performance and impacts of the media, as well as the role of the public in policy decision-making, Besley and Nisbet (2013) have argued that scientists consider the public as generally uninformed about sciences. They are critical of media coverage but believe that interactions with journalists are important for promoting science literacy as well as career advancement, policy makers being considered as the most important external stakeholders to engage with. Furthermore, on the basis of parallel surveys of scientists from multiple scientific societies, the most consistent predictors of willingness to take part in public engagement activities are a belief that the experience will be enjoyable and make a difference, as well as the time available to engage (Besley et al. 2018). Age, sex, scientific field but also the researcher's perception of the public, of her peers and of her personal engagement skills are inconsistent predictors.

Finally, a survey conducted in Belgium on higher education institutions of the Brussels Capital Region ( $N=727)$ showed that one respondent on two has experience in valorisation (Dobbels et al. 2015). The vast majority of respondents in SSH were concerned by social valorisation rather than economic valorisation - which is the main focus of knowledge transfer policies of the Brussels Region - contrarily to their peers in the exact and applied sciences. A majority of researchers agreed that researchers should contribute to valorisation, although $62 \%$ of the respondents consider that academics should remain free to valorise or not. Mentioned obstacles are the lack of time (85\%), lack of skills or dedicated funding (64\%) as well as lack of reward (60\%). Valorisation is perceived like a personal affair, rather than a professional opportunity or necessity.

\section{DISCUSSION OF EXPLORATORY RESULTS}

We conducted 16 semi-structured interviews with senior researchers in sociology, having earned their PhD for at least eight years and active in Belgium, Croatia, Cyprus, Finland, Iceland, Lithuania, Poland and Slovenia. We interviewed them about their perceived roles in the definition, the dissemination and the implementation of the quality criteria and rationales that are to be used in evaluation situations. In particular, we wanted to know to what extent they consider it important that impact is taken into account in the evaluation of SSH research. We had previously agreed on a broad definition of impact, considering it as the result of all kinds of "productive interactions" (Spaapen and Van Drooge 2011) through which researchers engage with all kinds of non-academic publics.

Even if we will bring further nuances and developments to the analysis in a future publication, it is already possible to contend that our results do not essentially contradict the most important conclusions from the studies we reviewed above. In particular we have found that inter- viewees perceive the same isomorphic evolutions of higher education towards managerialism and internationalisation, and many also share to some degree an attitude of symbolic compliance with the related prescriptions.

In regards to our interviewees' perception and attitudes towards the impact agenda, it is quite clear that the impact agenda is not perceived as having currently any direct and significant incidence on their professional life. The real pressure is obviously on producing more papers, in the English language, in international journals, rather than on getting more interactions with the non-academic world. In some countries there is even a recent and very strong focus on the use of bibliometrics in SSH research assessment (e.g. Croatia, Poland), although dedicated funding tools for supporting "impacting" SSH research have also been put in other places (Belgium). Quantitative performance based evaluation of research is mostly perceived as being inconsistent with any stronger engagement in impact related activities, which some respondents associate with local research (and publications in vernacular language) and perceive as harder to properly quantify (Lithuania). In some cases (like in Slovenia), past evaluation processes involving general public in the evaluation process to higher extent may have been associated with more societally impacting research policies than what is currently the case.

However, some interviewees mention that it is still possible to reward - even if slightly - impact in the assessment (like in Finland or in Iceland) or that it may even be feasible in some cases to pursue a "parallel career" in academia, based on media engagement and the conduct of more operational research. "Open Science" (OS) and "Open Access" (OA) are not considered as priorities (at all) and some interviewees even perceive $\mathrm{OA}$ journals as being of a lower quality and/or reputation, or even as fostering the prevailing science system. One Belgian respondent underlines though that institutional OA repositories do allow the dissemination of a diversity of research outputs - beside scholarly articles - including those who may impact society.

In one Belgian researcher's perspective, impact should not be considered only in an instrumental perspective, but relies on the sociologists' duty to "engage in the city" in a scientifically informed but also critical way. An Icelandic respondent considers that interacting with the media is an intrinsic part of his academic job.

Finally, we would like to emphasise that several researchers - in particular those who do not have responsibilities in administrative areas (Cyprus) or do not belong to the new academic generation (Croatia) - wish that assessment takes better impact-related endeavours into account. As one of our Croatian respondents told us: "The responsibility of science is towards society and the community as they are funding us, and not just our personal scientific career or our motives. This is part of our social responsibility of being scientists. Often our scientific results have no impact. Nevertheless, it is our responsibility to interpret social processes even when we feel that our notions have no resonance. It is our responsibility to interpret social processes and try to be convincing, even through nonscientific publications such as policy documents or the like" ${ }^{\text {"3. }}$ 


\section{REFERENCES}

Anderson, G. (2008). Mapping academic resistance in the managerial university. Organization, 15(2), 251-270.

Auranen, 0., and Pölönen, J. (2014). "Julkaisufoorumi-luokitus ja kansallinen julkaiseminen" (Publication Forum rating and national publishing). In R. Muhonen and H.-M. Puuska (Eds.), Tutkimuksen kansallinen tehtävä. Tampere: Vastapaino, 153-175.

Barry, J., Chandler, J. and Clark, H. (2001). Between the ivory tower and the academic assembly line. Journal of Management Studies, 38(1), 87-101.

Besley, J. C., Dudo, A., Yuan, S. and Lawrence, F. (2018). Understanding scientists' willingness to engage. Science Communication, 40(5), 559-590.

Besley, J. C. and Nisbet, M. (2013). How scientists view the public, the media and the political process. Public Understanding of Science, 22(6), 644-659.

Bøgelund, P. (2015). How supervisors perceive PhD supervision-And how they practice it. International Journal of Doctoral Studies, 10(1), 39-55.

Chandler, J., Barry, J. and Clark, H. (2002). Stressing academe: The wear and tear of the new public management. Human Relations, 55(9), 1051-69.

Clarke, C., Knights, D., and Jarvis, C. (2012). A labour of love? Academics in business schools. Scandinavian Journal of Management, 28(1), 5-15.

Clegg, S. (2008). Academic identities under threat?. British Educational Research Journal, 34(3), 329-345.

European Commission (2018). Communication from the Commission to the European Parliament, the Council, the European Economic and Social Committee and the Committee and the Committee of the Regions: Horizon 2020 interim evaluation: maximising the impact of EU research and innovation. 11/01/2018.

Davies, S. R. and Horst, M. (2016). Science Communication: Culture, Identity and Citizenship. Springer.

Deem, R. (1998). 'New managerialism' and higher education: The management of performances and cultures in universities in the United Kingdom. International Studies in Sociology of Education, 8, 47-70.

Deem, R. (2003). "New managerialism in UK universities: manager-academic accounts of change". In H. Eggins (Ed.), Globalization and reform in Higher Education. Berkshire : Open University Press, 55-67.

De Rijcke, S., Wouters, P. F., Rushforth, A. D., Franssen, T. P. and Hammarfelt, B. (2016). Evaluation practices and effects of indicator use - a literature review. Research Evaluation, 26(2), 161-169.

Deuchar, R. (2008). Facilitator, director or critical friend?: Contradiction and congruence in doctoral supervision styles. Teaching in Higher Education, 13(4), 489-500.
DiMaggio, P. J. and Powell, W. W. (1983). The iron cage revisited: institutional isomorphism and collective rationality in organizational fields. American Sociological Review 48(2), 147-160.

DiMaggio, P. J. and Powell, W. W. (Eds.) (1991). The New Institutionalism in Organizational Analysis. Chicago: University of Chicago Press.

Dobbels, J., Kesbeke, W. and Ysebaert, W. (2015). Hoe onderzoekers werkelijk denken over valoriseren. THandMA, 1: 93-97.

Enders, J., De Boer, H. and Leišytè, L. (2009). "New Public Management and the Academic Profession: the Rationalisation of Academic Work Revisited". In J. Enders, and E. de Weert (Eds.), The Changing Face of Academic Life: analytical and comparative perspectives. New York : Palgrave-Macmillan, 36-57.

Gibbons, M., Limoges, C., Nowotny, H., Schwartzman, S., Scott, P. and Trow, M. (1994). The new production of knowledge: The dynamics of science and research in contemporary societies. London: Sage.

Giménez-Toledo, E., Mañana-Rodríguez, J., Engels, T. C. E., Ingwersen, P., Pölönen, J., Sivertsen, G., Verleysen, F. T. and Zuccala, A. A. (2016). Taking scholarly books into account: Current developments in five European countries. Scientometrics, 107(2), 685-699.

Gingras, Y. (2017). Sociologie des sciences. Presses universitaires de France.

Gläser, J. and Laudel, G. (2016). Governing science: how science policy shapes research content. European Journal of sociology/Archives Européennes de sociologie, 57(1), 117-168.

Hammarfelt, B. and de Rijcke, S. (2015). Accountability in context: effects of research evaluation systems on publication practices, disciplinary norms, and individual working routines in the faculty of Arts at Uppsala University. Research Evaluation, 24(1), 63-77.

Hammarfelt, B., Nelhans, G., Eklund, P. and Åström, F. (2016). The heterogeneous landscape of bibliometric indicators. Evaluating models for allocating resources at Swedish universities. Research Evaluation, 25(3), 292-305.

Hood, C. 1995. The 'new public management' in the 1980s: Variations on a theme. Accounting, Organizations and Society, 20, 93-109.

Jiménez-Contreras, E., de Moya Anegón, F. and López-Cózar, E. D. (2003). The evolution of research activity in Spain: The impact of the National Commission for the Evaluation of Research Activity (CNEAI). Research policy, 32(1), 123-142.

Kalfa, S., Wilkinson, A. and Gollan, P. J. (2018). The academic game: Compliance and resistance in universities. Work, Employment and Society, 32(2), 274-291.

Kaltenbrunner, W. and de Rijcke, S. (2017). Quantifying 'Output' for Evaluation: Administrative Knowledge Politics and Changing Epistemic Cultures in Dutch Law Faculties. Science and Public Policy, 44(2), 284-293. 
Kattel, R. and Mazzucato, M. (2018). Mission-oriented innovation policy and dynamic capabilities in the public sector. Industrial and Corporate Change, 27(5), 787-801.

Kehm, B. M. and Leiðytë, L. (2010). "Effects of New Governance on Research in the Humanities -The Example of Medieval History". In D. Jansen (Ed.), Governance and Performance in the German, Public Research Sector. Dordrecht: Springer, 73-90.

Kirkpatrick, I. and Ackroyd, S. (2003). Transforming the professional archetype? The new managerialism in UK social services. Public Management Review, 5(4), 511-531.

Kulczycki, E., Engels, T. C., Pölönen, J., Bruun, K., Dušková, M., Guns, R., Nowotniak, R., Petr, M., Sivertsen, G., IsteniĐ StarĐiĐ, A. and Zuccala, A. (2018). Publication patterns in the social sciences and humanities: evidence from eight European countries. Scientometrics, 116(1), 463-486.

Lam, A. (2010). From "ivory tower traditionalists" to "entrepreneurial scientists"? Academic scientists in fuzzy university-industry boundaries. Social Studies of Science, 40(2), 307-340.

Leathwood, C. and Read, B. (2013). Research policy and academic performativity: compliance, contestation and complicity. Studies in Higher Education, 38(8), 1162-1174.

Lee, A. (2008). How are doctoral students supervised? Concepts of doctoral research supervision. Studies in Higher Education, 33(3), 267-281.

Leisyte, L. (2007). University governance and academic research: Case studies of research units in Dutch and English universities. PhD thesis, University Twente.

Linková, M. (2014). Unable to resist: Researchers' responses to research assessment in the Czech Republic. Human Affairs, 24(1), 78-88.

Linková, M. and Stöckelová, T. (2012). Public accountability and the politicization of science: The peculiar journey of Czech research assessment. Science and Public Policy, 39(5), 618-629.

Merton, R. K. (1973) [1942]. "The Normative Structure of Science". In R.K. Merton, The Sociology of Science: Theoretical and Empirical Investigations. Chicago: University of Chicago Press, 267-278.

Morris, N. and Rip, A. (2006). Scientists' coping strategies in an evolving research system: The case of life scientists in the UK. Science and Public Policy, 33(4), 253-263.

O'Carroll, C., Rentier, B., Cabello Valdès, C., Esposito, F., Kaunismaa, E., Maas, K., Metcalfe, J., McAllister, D. and Vandevelde, K. (Eds.) (2017). Evaluation of Research Careers fully acknowledging Open Science Practices. Rewards, incentives and/or recognition for researchers practicing Open Science. Publication Office of the European Union.

Oliver, C. (1991). Strategic responses to institutional processes. Academy of management review, 16(1), 145-179.
Pölönen, J. and Wahlfors, L. (2016). "Local use of a national rating of publication channels in Finnish universities". Poster presented at the 21st Nordic Workshop on Bibliometrics and Research Policy, Copenhagen, 3.-4.11.2016. URL: https://figshare.com/articles/Local_Use_of_a_ National_Rating_of_Publication_Channels_in_Finnish_Universities_ NWB_2016_poster_/4246541.

Sivula, A., Suominen, J. and Reunanen, M. (2015). A1 alkuperäisartikkeli tieteellisessä aikakauslehdessä. Uusien julkaisukäytänteiden omaksuminen ihmistieteissä 2000-luvulla. Kasvatus and Aika, 9(3), 149-171.

Smith, K. (2010). Research, Policy and Funding - Academic Treadmills and the Squeeze on Intellectual Spaces. The British Journal of Sociology, 61 (1), 176-195.

Spaapen, J. and Van Drooge, L. (2011). Introducing 'productive interactions' in social impact assessment. Research Evaluation, 20(3), 211-218.

Stöckelová, T. (2012). Immutable mobiles derailed: STS and the epistemic geopolitics of research assessment. Science, Technology and Human Values, 37(2), 286-311.

Teelken, C. (2011). Compliance or pragmatism: how do academics deal with managerialism in higher education? A comparative study in three countries. Studies in Higher Education, 37(3), 271-290.

Vanholsbeeck, M. (2012). Entre qualité prescrite et qualité souhaitable. Quaderni, 77, 71-84.

Vanholsbeeck, M. (2016). La notion de "qualité» des publications dans l'évaluation de la recherche et des chercheurs en sciences humaines et sociales: Le potentiel de l'Open Access pour dépasser le paradoxe des prescriptions en matière de qualité et l'ambivalence de leur perception par les chercheurs en sciences de la communication. PhD thesis, Université Libre de Bruxelles.

Vanholsbeeck, M. (2017). La notion de Science Ouverte dans l'Espace européen de la recherche: Entre tendances à l'«exotérisation» et à la "gestionnarisation» de la recherche scientifique. Revue française des sciences de l'information et de la communication, 11.

Weingart, P. (2005). Impact of bibliometrics upon the science system: Inadvertent consequences?. Scientometrics, 62(1), 117-131.

Whitley, R. and Gläser, J. (2014). The impact of institutional reforms on the nature of universities as organisations. In R. Whitley, and J. Gläser (Eds.), Organizational Transformation and Scientific Change: The Impact of Institutional Restructuring on Universities and Intellectual Innovation. Emerald Group Publishing Limited, 19-49.

Ylijoki, 0.-H. (2003). Entangled in academic capitalism? A case-study on changing ideals and practices of university research. Higher Education, 45, 307-35.

Ylijoki, 0.-H. and Ursin, J. (2013). The construction of academic identity in the changes of Finnish higher education. Studies in Higher Education, 38(8), 1135-1149. 


\section{AUTHORS}

\section{MARC VANHOLSBEECK}

Department of Information and Communication Studies, Université Libre de Bruxelles

30 Depage Avenue (level 11), Brussels, 1050 (Belgium)

E: mvholsbe@ulb.ac.be

\section{THEODOSIA DEMETRIOU}

Department of Education, 4

6 Makedonitissas Avenue, CY-2417, P.0.Box 24005, Nicosia, 1700

(Cyprus)

E: demetriou.th@unic.ac.cy

\section{AGNE GIRKONTAITE}

Department of Sociology, Vilnius University

Universiteto str. 9, room 309, Vilnius, 01513 (Lithuania)

E: agne.girkontaite@fsf.vu.It

\section{ANDREJA ISTENIC STARCIC}

University of Primorska, Faculty of Education

Cankarjeva 5, Koper, 6000 (Slovenia)

University of Ljubljana, Faculty of Civil and Geodetic Engineering

Jamova 2, Ljubljana, 1000 (Slovenia)

E: andreja.starcic@gmail.com

\section{VILLE KEISKI}

University of Jyväskylä, Department of Social Sciences and Philosophy, Opinkivi, Keskussairaalantie 2, P0 Box 35, 40014 (Finland)

E: ville.keiski@jyu.fi

\section{EMANUEL KULCZYCKI}

Scholarly Communication Research Group, Adam Mickiewicz University, Szamarzewskiego 89c, Poznań, 60-568 (Poland)

E: emek@amu.edu.pl

\section{ELENA PAPANASTASIOU}

School of Education, Department of Education

46 Makedonitissas Avenue, CY-2417, P.0.Box 24005, Nicosia, 1700

(Cyprus)

E: papanastasiou.e@unic.ac.cy

\section{JANNE PÖLÖNEN}

Publication Forum, Federation of Finnish Learned Societies

Snellmaninkatu 13, Helsinki, 00170 (Finland)

E: janne.polonen@tsv.fi

\section{HULDA PROPPE}

Háskóli Islands / University of Iceland, Gimli

Sæmundargata 2, Reykjavi, 101 (Iceland)

E: hproppe@hi.is

\section{MAJA VEHOVEC}

Institute of Economics

Trg J. F. Kennedyja 7, Zagreb, 10000 (Croatia)

E: mvehovec@eizg.hr 